\title{
Comparison of Stone Scoring Systems in Predicting Outcomes of Percutaneous Nephrolithotomy in Patients with Solitary Kidney
}

\section{Tek Böbrekli Hastalarda Uygulanan Perkütan Nefrolitotominin Sonuçlarını Tahmin Etmede Taș Skorlama Sistemlerinin Karşılaștırılması}

\author{
(D) Volkan Çağlayan, (D) Sedat Öner, (D) Efe Önen, (D) Sinan Avcı, (D) Metin Kılıç, (D) Uğur Akgün \\ Bursa Provincial Health Directorate Health Sciences University, Bursa Higher Specialization Training and Research Hospital, Clinic of Urology, \\ Bursa, Turkiye
}

\section{What's known on the subject? and What does the study add?}

There are various studies in the literature evaluating the efficacy of stone scoring systems in predicting the outcomes and postoperative complications of percutaneous nephrolithotomy. The treatment of kidney stones in patients with solitary kidney is a challenge for the surgeon. When we searched the literature, we observed that there is no study evaluating the efficacy of scoring systems in patients with solitary kidney. In our study, it was shown that Clinical Research Office of the Endourology Society nomogram was the most effective factor in predicting the outcome of the surgery, but both scoring systems were not effective in predicting postoperative complications.

\begin{abstract}
Objective: To assess efficacy of the Guy's Stone score (GSS) and Clinical Research Office of the Endourological Society (CROES) nomogram in predicting outcomes of percutaneous nephrolithotomy (PCNL) in patients with solitary kidney.

Materials and Methods: Ninety patients with solitary kidney, who underwent PCNL between 2010 and 2018 in our center, were evaluated. Demographic characteristics and preoperative laboratory results of the patients were recorded. Operative time, duration of anesthesia, access number, stone location, supracostal access, stone-free (SF) rate, complication rate, nephrostomy tube removal time and length of hospital stay were recorded.

Results: Data of patients with residual stones and SF patients were compared. In the analysis of groups; GSS, CROES score, stone burden, preoperative creatinine value, multiple accesses and presence of staghorn stone were found to be significant factors related with SF status. When data was evaluated according to complication status, stone burden, GSS, CROES score, multiple accesses and stone location were significant factors. In multivariate analysis, the most significant factors in predicting SF and complication status were CROES score ( $p=0.019)$ and stone burden ( $p=0.012$ ), respectively.

Conclusion: PCNL is an effective method in the treatment of stones in solitary kidney. CROES score is a better predictor of SF status in patients with solitary kidney. Patients with high stone burden are more prone to complications.
\end{abstract}

Keywords: Percutaneous nephrolithotomy, Solitary kidney, Guy's Stone score, CROES nomogram

Öz

Amaç: Guy Taş skorunun (GSS) ve Endouroloji Derneği Klinik Araştırma Ofisi (CROES) nomogramının tek böbrekli hastalarda perkütan nefrolitotomi (PCNL) sonuçlarını öngörmedeki etkinliğini değerlendirmek.

Gereç ve Yöntem: Kliniğimizde 2010 ve 2018 yılları arasında PCNL uygulanan tek böbrekli 90 hasta değerlendirildi. Hastaların demografik özellikleri ve preoperatif laboratuvar sonuçları kaydedildi. Operasyon süresi, anestezi süresi, akses sayısı, taş yerleşimi, suprakostal erişim, taşsızlık oranı (T0), komplikasyon oranı, nefrostomi çekim süresi ve hastanede kalış süresi kaydedildi.

Bulgular: Rezidüel taşlı ve taşsız hastaların verileri karşılaştırıldı. Grupların analizinde; GSS, CROES skoru, taş yükü, preoperatif kreatinin değeri,

Correspondence: Volkan Çağlayan MD, Bursa Provincial Health Directorate Health Sciences University, Bursa Higher Specialization Training and Research Hospital, Clinic of Urology, Bursa, Turkiye

E-mail: volkantuysuz@hotmail.com ORCID-ID: orcid.org/0000-0001-9303-9585

Received: 07.07.2019 Accepted: 23.09.2019

Cite this article as: Çağlayan V, Öner S, Önen E, Avcı S, Kılıç M, Akgün U. Comparison of Stone Scoring Systems in Predicting Outcomes of Percutaneous Nephrolithotomy in Patients with Solitary Kidney. J Urol Surg 2020;7(1):1-7.

๑Copyright 2020 by the Association of Urological Surgery / Journal of Urological Surgery published by Galenos Publishing House. 
çoklu akses ve staghorn taş varlığı TO durumu ile ilişkili önemli faktörlerdi. Veriler komplikasyon durumuna göre değerlendirildiğinde; taş yükü, GSS, CROES skoru, çoklu akses ve taş yerleşimi önemli faktörlerdi. Çok değişkenli analizlerde TO ve komplikasyon durumunu öngörmede en önemli faktörler sırasıyla CROES skoru $(p=0,019)$ ve taş yükü $(p=0,012)$ idi.

Sonuç: PCNL, tek böbrekli hastalarda taşların tedavisinde etkili bir yöntemdir. CROES skoru tek böbreği olan hastalarda TO durumu için daha iyi bir belirleyicidir. Yüksek taş yükü olan hastalar komplikasyonlara daha yatkındır.

Anahtar Kelimeler: Perkütan nefrolitotomi, Tek böbrek, Guy Taş skoru, CROES nomogramı

\section{Introduction}

Renal stone treatment in solitary kidney is a challenge for urologists. Although it is hard to make decision for surgeons in the treatment of the patients with solitary kidney, there is no different recommendation in the current guidelines for such special cases. In the current European Association of Urology guidelines, while retrograde intrarenal surgery (RIRS), percutaneous nephrolithotomy (PCNL) and extracorporeal shock wave lithotripsy (ESWL) are equally suggested for the treatment of stones in the range 1 to $2 \mathrm{~cm}, \mathrm{PCNL}$ is the treatment of choice for kidney stones larger than $2 \mathrm{~cm}(1)$. In the literature, there are various studies evaluating the effectiveness of PCNL in solitary kidneys, which revealed stone free rates (SFRs) between $59 \%$ and $100 \%(2,3,4,5,6)$. Despite the satisfactory success rate of the procedure, many surgeons may prefer less invasive methods considering the possible complications especially in patients with solitary kidney. As known, PCNL is described as a safe method for stone removal, however, it is associated with some complications such as fever, urinary tract infection, bleeding requiring transfusion, neighboring organ injury, loss of the kidney and death (7). Additionally, it should be taken into consideration that patients with solitary kidney have a thicker parenchyma as a result of compensatory hypertrophy and are more prone to bleeding. Possibility of total nephrectomy due to uncontrollable bleeding, which leads to a life-long hemodialysis or transplantation requirement, is a primary concern for the patient and the surgeon.

Recently, different stone scoring systems have been developed to assist surgeons in predicting surgical outcomes of PCNL $(8,9,10,11)$. Guy's Stone score (GSS) and the Clinical Research Office of the Endourological Society (CROES) nomogram are two of the most widely used scoring systems. GSS consists of four grades based on stone burden, stone location, and anatomical features of the kidney. Higher GSS is associated with decreased SFR. The CROES nomogram is consisted of variables such as size, number and location of the stone, previous treatment, presence of staghorn stone and number of cases treated per year in the institution. Each factor has a score between 0 and 100 and SFR correlates positively with the increase of the total score. In the previously published articles, it was demonstrated that both scoring systems were correlated well with SFR $(12,13,14)$ and they had similar ability in predicting surgical outcomes $(15,16,17,18)$.
In the current study, we aimed to analyze the data of patients with solitary kidney who underwent PCNL in our institute and assess the efficiency of GSS and CROES nomogram in predicting stone-free status and complication status.

\section{Materials and Methods}

After institutional review board approval (protocol no: 2011KAEK-25 2018/10-02), the data of 90 patients with solitary kidney, who underwent PCNL between November 2010 and June 2018 was, evaluated.

The procedure was performed in patients with stones greater than $2 \mathrm{~cm}$, patients with ESWL-resistant stones, and patients who selected PCNL after receiving information about treatment alternatives.

Patients, who had congenital solitary kidney, patients who had a contralateral kidney which is non-functional or which contributes less than 15\% to total function (19) and those who had undergone nephrectomy, were included in the study.

\section{Preoperative Evaluation}

Detailed physical examinations, history taking, blood count, blood biochemistry assays, estimated glomerular filtration rate (eGFR), urine analysis and urine culture were performed. The Chronic Kidney disease epidemiology collaboration formula was used to calculate eGFR (20). Kidney-ureter-bladder radiography, ultrasonography and computed tomography (CT) were performed for each patient. Stone size was calculated using CT images. The two largest diameters were multiplied to calculate the stone burden. All the calculations (stone size, GSS, CROES score) were performed by the same surgeon.

Prophylactic antibiotic administration was performed one hour prior to the procedure. Appropriate antibiotic therapy was administered in patients with positive urine culture and the procedure was delayed until the sterile urine culture was seen.

\section{Surgical Procedure}

The procedures were performed under general anesthesia by different experienced surgeons. Following the insertion of a $6 \mathrm{~F}$ ureteral catheter, the patients were turned to the prone position. Contrast agent was injected through the catheter to visualize the renal collecting system. Access was performed 
under fluoroscopic guidance. After access was obtained, a guide wire was inserted into the collecting system. Serial dilators were used to dilate the access tract and a $30 \mathrm{~F}$ Amplatz sheath was positioned. Stone fragmentation was performed with a pneumatic lithotripter. The fragments were extracted using a stone basket or a grasper. Smaller fragments were extracted by irrigation. At the end of the procedure, antegrade pyelography was performed to check stone clearance and a nephrostomy tube was inserted under fluoroscopy guidance.

The demographic characteristics of the patients, such as age, gender, and laterality, operative time, anesthesia time, access number, stone location (located in a single calyx or in multiple calyces), presence of supracostal access, SFR, complication rate, nephrostomy removal time and length of hospital stay were recorded and evaluated.

The nephrostomy catheter was removed after recovery of hematuria. Stone clearance was assessed with CT 3 weeks after the procedure. If there were no stone fragments on the images, the procedure was defined as SF. Clinically insignificant residual fragments (CIRFs) were defined as the presence of fragments $<4 \mathrm{~mm}$ which are non-obstructive, non-infectious and asymptomatic. PCNL-associated complications were recorded and classified according to the Clavien classification $(21,22)$.

\section{Statistical Analysis}

Distribution of continuous variables was evaluated using the one-sample Kolmogorov-Smirnov test. Comparisons between groups were evaluated using the Pearson's chi-squared test and Fisher exact test for categorical variables and using the MannWhitney $\mathrm{U}$ test or independent samples t-test for continuous variables. Logistic regression analysis was performed to evaluate the independent factors associated with complication and SF status. Statistical analysis was performed using SPSS 16.0 for windows software (SPSS, Inc., Chicago, IL) and a p value of less than 0.05 was considered statistically significant.

\section{Results}

Of the 90 patients who underwent PCNL, 60 were male and 30 were female. The median age of the patients was 52 years (21-83). The procedures were performed for stones in the right kidney in 47 patients and in the left kidney in 43. Descriptive values of the total cohort are showed in Table 1. The causes of having solitary kidney were contralateral nephrectomy (50 patients), non-functional kidney (11 patients), congenital agenesis (8 patients) and contralateral kidney which contributed less than 15\% to total renal function in dimercaptosuccinic acid scintigraphy (21 patients).

The data of the patients with residual stones and SF patients were compared. Patients with CIRFs were included in the group with residual stones. The SF rate was 81.1\% (73 patients) after a single session. The procedure was unsuccessful in 5 patients and there were CIRFs found on the images in 12 patients. ESWL was performed after 5 unsuccessful operations and stone clearance was achieved in 3. In the patients with CIRFs, the stones were stable, so they were followed up. In the analysis of the groups; GSS ( $p=0.005)$, CROES score $(p=0.001)$, stone burden $(p=0.002)$, preoperative creatinine value $(p=0.009)$, multiple accesses $(p=0.003)$, presence of staghorn stone $(p=0.001)$, and to have stones located in multiple calyces ( $p=0.043)$ were the significant factors associated with SF status. Although the median creatinine value was significantly higher in patients with residual stones, eGFR was not found to be a significant factor. The evaluation of factors associated with SF status is demonstrated in Table 1.

In our series, complications occurred in 17 patients. There were 5 grade 1,15 grade 2 and 2 grade 3 complications (Table 2). When the patients were evaluated according to the complication status, stone burden $(p<0.001)$, GSS $(p=0.05)$, CROES score $(p=0.005)$, multiple accesses $(p=0.003)$ and presence of staghorn stone $(p=0.009)$ were the statistically significant factors (Table 3 ).

Univariate and multivariate analyses of the factors affecting SF status and complication status are demonstrated in Table 4. In the multivariate analysis by using the forced-entry method, no independent factor associated with SF or complication status was found. In backward elimination, the most significant factor to predict SF status was CROES score $(p=0.019)$ and the most significant factor to predict complication status was stone burden $(p=0.012)$.

\section{Discussion}

PCNL in patients with solitary kidney poses a significant challenge for the urologist. Taking the sole functioning kidney into account, the aims of the procedure should be to achieve maximum stone clearance in a single session and avoid complications affecting renal function. When we searched the literature, we found various studies assessing the efficacy of nephrolithometric systems in predicting surgical outcomes. However, we could not find a topic comparing the efficacy of those for PCNL in solitary kidney.

In a study performed by Bucuras et al. (2), data of 189 patients with solitary kidney who underwent PCNL was compared with patients with two normal functioning kidneys. SFR was significantly lower (65.4\% to $76.1 \%$ ) and blood transfusion rate was higher $(10.1 \%$ to $5.6 \%)$ in patients with solitary kidney. Also a higher cardiovascular risk and American Society of Anesthesiologists (ASA) score were seen in this group. The higher rate of blood transfusion was related with factors such as higher ASA score, more prevalent anticoagulant use and thicker parenchyma. No statistically significant difference was observed 


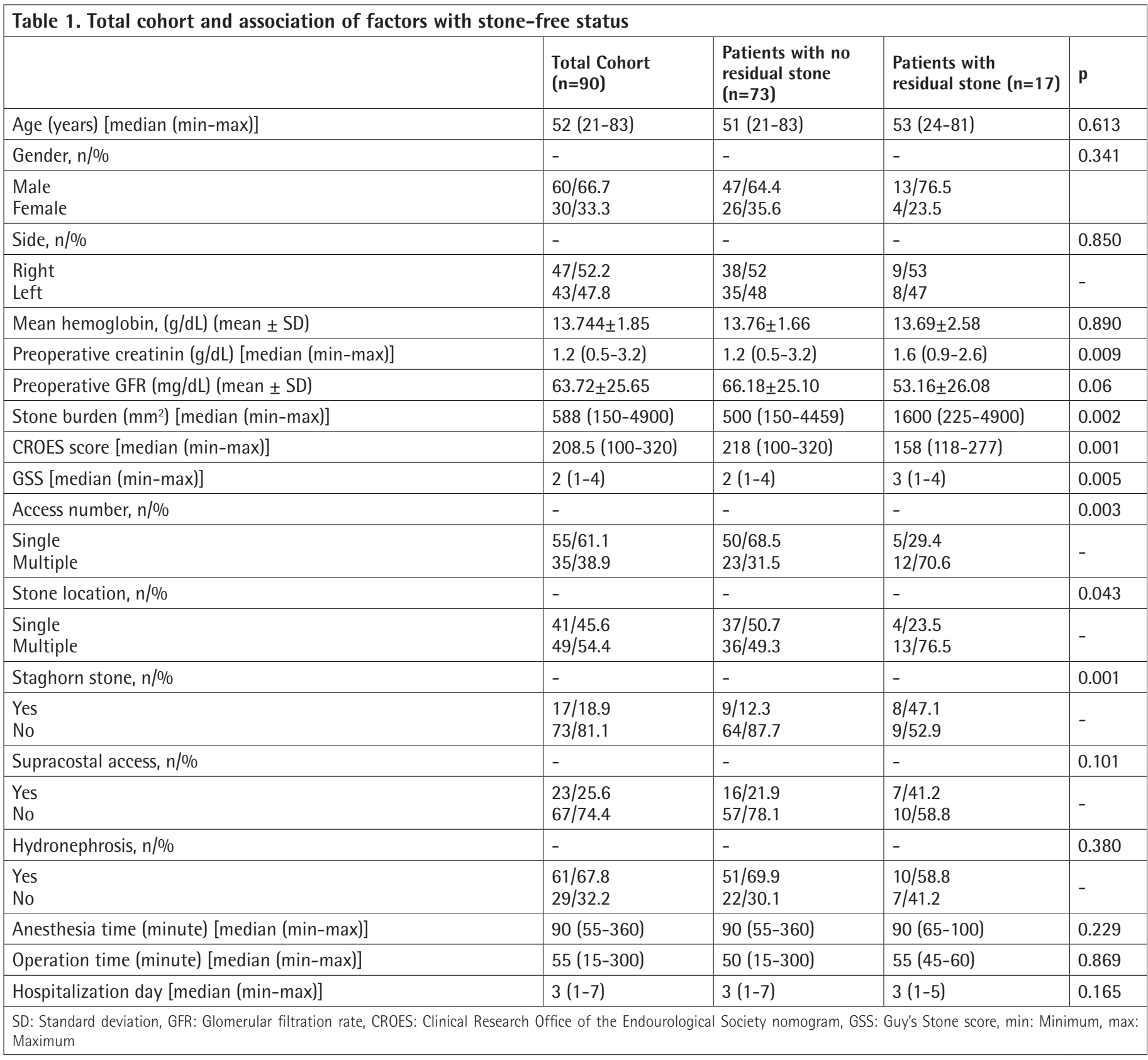

between the groups when the rates of other complications (fever, hydrothorax, perforation, etc.) were evaluated. The significantly lower SFR was associated with surgeon's not taking risks in stone removal in solitary kidneys to avoid complications (2). In another study, data of 412 patients with single functioning kidney was investigated. SFR and complication rate were $91.3 \%$ and $19.2 \%$, respectively. Blood transfusion was required in 19 patients $(4.6 \%)$ and it was associated with uremia and lower preoperative hemoglobin levels due to the uremia (23). In our study, the mean GFR value was lower in patients with residual stones and in patients with complications, however, no statistically significant difference was revealed.

\begin{tabular}{|l|l|}
\hline \multicolumn{2}{|l|}{ Table 2. Complications according to Clavien classification } \\
\hline Clavien grade 1 & $5 / 5.55$ \\
\hline Fever, $\mathrm{n} / \%$ & $15 / 16.7$ \\
\hline Clavien grade $\mathbf{2}$ & \\
\hline Blood transfusion, $\mathrm{n} / \%$ & $2 / 1.8$ \\
\hline Clavien grade 3 & $\begin{array}{l}\text { Nephrostomy tract urine leakage requiring Double } \\
\text { J-stent, } \mathrm{n} / \%\end{array}$ \\
\hline
\end{tabular}

Wong and associates evaluated data of 22 PCNLs which were performed in 17 solitary kidney patients. SFR was 59\%. There 
were 3 Clavien 2 complications (sepsis in 2 patients, blood transfusion in 1) and 2 Clavien 3 complications (double J -stenting requirement). The relatively low SFR was associated with higher GSS than in similar studies evaluating the outcomes of PCNL in solitary kidney (4).

In a study performed by Torricelli and co-workers, data of 27 patients with solitary kidney who underwent PCNL were evaluated. SFR was 67\%. Postoperative complications occurred in 8 patients (29.6\%) (5 Clavien 2 and 3 Clavien 3). GSS was calculated for each patient and $45 \%$ of the patients were classified as having GSS 3 or 4 . Conversely with our study, GSS was not associated with complication status. On univariate analysis, prolonged operative time was the only factor associated with complication status (24).

As mentioned above, there are several studies comparing the efficacy of GSS and CROES nomogram in the literature. In a study performed by Bozkurt et al. (15), the efficacy of GSS and CROES nomogram in predicting SFR and complication rate was compared. Both scoring systems had similar accuracy in predicting SFR. Also the analysis showed that both scoring systems revealed significant efficacy in predicting postoperative complications (15). In a multicenter study performed by Labadie et al. (16), a total of 246 patients, who underwent PCNL between 2009 and 2012, were evaluated. Multivariate logistic

\begin{tabular}{|c|c|c|c|}
\hline & $\begin{array}{l}\text { Patients without } \\
\text { complication }(n=73)\end{array}$ & $\begin{array}{l}\text { Patients with } \\
\text { complication }(n=17)\end{array}$ & p \\
\hline Age (years) [median (min-max)] & $54(21-83)$ & $52(34-70)$ & 0.556 \\
\hline Gender, n/\% & - & - & 0.446 \\
\hline $\begin{array}{l}\text { Male } \\
\text { Female }\end{array}$ & $\begin{array}{l}50 / 68.5 \\
23 / 31.5\end{array}$ & $\begin{array}{l}10 / 58.8 \\
7 / 41.2\end{array}$ & - \\
\hline Side, $\mathrm{n} / \%$ & - & - & 0.790 \\
\hline $\begin{array}{l}\text { Right } \\
\text { Left }\end{array}$ & $\begin{array}{l}39 / 53.4 \\
34 / 46.6\end{array}$ & $\begin{array}{l}8 / 47 \\
9 / 53\end{array}$ & - \\
\hline Mean hemoglobin $(\mathrm{g} / \mathrm{dL})[$ mean $\pm \mathrm{SD}]$ & $13.97 \pm 1.77$ & $13.15 \pm 1.90$ & 0.113 \\
\hline Preoperative creatinin $(\mathrm{mg} / \mathrm{dL})$ [median (min-max)] & $1.2(0.5-3.1)$ & $1.3(0.7-3.2)$ & 0.615 \\
\hline Preoperative GFR $(\mathrm{mg} / \mathrm{dl})[\mathrm{mean} \pm \mathrm{SD}]$ & $64.66 \pm 25.24$ & $59.69 \pm 27.82$ & 0.475 \\
\hline Stone burden $\left(\mathrm{mm}^{2}\right)$ [median (min-max)] & $452(150-4900)$ & $1600(500-4459)$ & $<0.001$ \\
\hline CROES score [median (min-max)] & $216(100-320)$ & $158(137-289)$ & 0.005 \\
\hline GSS [median (min-max)] & $2(1-4)$ & $2(1-4)$ & 0.05 \\
\hline Access number, n/\% & - & - & 0.003 \\
\hline $\begin{array}{l}\text { Single } \\
\text { Multiple }\end{array}$ & $\begin{array}{l}50 / 68.5 \\
23 / 31.5\end{array}$ & $\begin{array}{l}5 / 29.4 \\
12 / 70.6\end{array}$ & - \\
\hline Stone location, n/\% & - & - & 0.138 \\
\hline $\begin{array}{l}\text { Single } \\
\text { Multiple }\end{array}$ & $\begin{array}{l}36 / 49.3 \\
37 / 50.7\end{array}$ & $\begin{array}{l}5 / 29.4 \\
12 / 70.6\end{array}$ & - \\
\hline Staghorn stone, $\mathrm{n} / \%$ & - & - & 0.009 \\
\hline $\begin{array}{l}\text { Yes } \\
\text { No }\end{array}$ & $\begin{array}{l}10 / 13.7 \\
63 / 86.3\end{array}$ & $\begin{array}{l}7 / 41.2 \\
10 / 58.8\end{array}$ & - \\
\hline Supracostal access, n/\% & - & - & 0.24 \\
\hline $\begin{array}{l}\text { Yes } \\
\text { No }\end{array}$ & $\begin{array}{l}18 / 22.8 \\
61 / 77.2\end{array}$ & $\begin{array}{l}5 / 29.4 \\
12 / 70.6\end{array}$ & - \\
\hline Hydronephrosis, n/\% & - & - & 0.065 \\
\hline $\begin{array}{l}\text { Yes } \\
\text { No }\end{array}$ & $\begin{array}{l}46 / 63 \\
27 / 37\end{array}$ & $\begin{array}{l}15 / 88.2 \\
2 / 11.8\end{array}$ & - \\
\hline Anesthesia time (minute) [median (min-max)] & $90(55-190)$ & $85(55-360)$ & 0.749 \\
\hline Operation time (minute) [median (min-max)] & $55(15-145)$ & $60(20-300)$ & 0.531 \\
\hline Hospitalization day [median (min-max)] & $3(1-7)$ & $3(1-7)$ & 0.448 \\
\hline
\end{tabular}


Table 4. Univariate and multivariate analyses of factors affecting stone-free status and complication status

\begin{tabular}{|c|c|c|c|}
\hline & \multicolumn{3}{|l|}{$p$ values } \\
\hline & \multirow[b]{2}{*}{$\begin{array}{l}\text { Univariate } \\
\text { analysis }\end{array}$} & \multicolumn{2}{|c|}{ Multivariate analysis } \\
\hline & & $\begin{array}{l}\text { Logistic } \\
\text { regression } \\
\text { (enter } \\
\text { method) }\end{array}$ & $\begin{array}{l}\text { Logistic regression } \\
\text { (backward- } \\
\text { stepwise method) }\end{array}$ \\
\hline \multicolumn{4}{|l|}{ Stone-free status } \\
\hline $\begin{array}{l}\text { Stone burden } \\
\text { CROES score } \\
\text { GSS } \\
\text { Access number } \\
\text { Stone location } \\
\text { Staghorn stone }\end{array}$ & $\begin{array}{l}0.003 \\
0.002 \\
0.002 \\
0.005 \\
0.048 \\
0.002\end{array}$ & $\begin{array}{l}0.502 \\
0.124 \\
0.361 \\
0.118 \\
0.191 \\
0.464\end{array}$ & $\begin{array}{l}0.019 \text { (Step 5) } \\
0.095 \text { (Step 5) }\end{array}$ \\
\hline \multicolumn{4}{|c|}{ Complication status } \\
\hline $\begin{array}{l}\text { Stone burden } \\
\text { CROES score } \\
\text { GSS } \\
\text { Access number } \\
\text { Staghorn stone }\end{array}$ & $\begin{array}{l}0.001 \\
0.008 \\
0.027 \\
0.005 \\
0.013\end{array}$ & $\begin{array}{l}0.111 \\
0.375 \\
0.328 \\
0.080 \\
0.514\end{array}$ & 0.012 (Step 4) \\
\hline \multicolumn{4}{|c|}{$\begin{array}{l}\text { CROES: Clinical Research Office of the Endourological Society nomogram, GSS: Guy's } \\
\text { Stone score, } \\
\text { Continuous variables: CROES, GSS, stone burden } \\
\text { Categorical variables: Access number (single-multiple), stone location (single calyx- } \\
\text { multiple calyces), staghorn stone (yes-no) }\end{array}$} \\
\hline
\end{tabular}

regression analysis showed that all the scoring systems were significantly correlated with SF status. Also, GSS and S.T.O.N.E nephrolithometry score were significantly associated with length of hospital stay and estimated blood loss while CROES score was not (16).

In the current study, SFR and complication rate were consistent with other studies. However, we found a higher rate of blood transfusion in our series. This condition was related with a more protective clinical approach to patients with solitary kidney and larger stone size compared to other studies. In the analysis, stone burden was associated with SFR and complication rate. The main purpose of this study was to evaluate the efficacy of GSS and CROES score in predicting SFR and complication status in patients with solitary kidney. Both scoring systems were correlated with SFR and complication status. In multivariate analysis of factors affecting SFR, CROES score was the only independent factor associated with SF status.

Concerns of patients and surgeons about the complications of PCNL are more disturbing before procedures on single functioning kidney. Recently, RIRS has been reported to provide a high SFR with low complication rate and relatively less life-threatening complications $(25,26)$. RIRS was defined as a successful treatment modality for stones in solitary kidneys but a decrease in SFR was reported especially for stones larger than $2 \mathrm{~cm}$ (27). Requirement of follow-up procedures after RIRS may add new risks and prolong the duration of treatment. We think that especially in solitary kidney, the modality of stone treatment should be selected according to surgeon's experience and patient's status.

The predictability of complications is an advantage for surgeon in the pretreatment patient preparation and peroperative decision taking. We think that the development of a PCNLspecific tool for predicting complication status is important. Our analysis revealed that neither GSS nor CROES score was effective enough in predicting complication prior to PCNL in solitary kidneys.

There are some limitations of the current study. First, the data was collected from a retrospective cohort. Second, we could not evaluate the efficacy of S.T.O.N.E nephrolithometry score due to lack of stone density in our cohort. Third, it was a single-center study which may limit generalizability.

\section{Conclusion}

PCNL is an effective method in the treatment of renal stones in solitary kidney. CROES nomogram score is a better tool in predicting SF status in patients with solitary kidney who are candidates for PCNL. Patients with high stone burden are more prone to complications. Further studies should be performed to evaluate the efficacy of nephrolithometric scoring systems in predicting surgical outcomes after PCNL in patients with solitary kidney.

\section{Ethics}

Ethics Committee Approval: Institutional review board approval (protocol no: 2011-KAEK-25 2018/10-02).

Informed Consent: Retrospective study.

Peer-review: Externally peer-reviewed.

\section{Authorship Contributions}

Concept: V.Ç., S.Ö., Design: V.Ç., S.Ö., Data Collection or Processing: V.Ç., S.A., U.A., Analysis or Interpretation: V.Ç., E.Ö., M.K., Literature Search: V.Ç., M.K., Writing: V.Ç., E.Ö.

Conflict of Interest: No conflict of interest was declared by the authors.

Financial Disclosure: The authors declare that they have no relevant financial.

\section{References}

1. Türk C, Knoll T, Petrik A, Sarica K, Skolarikos A, Straub M, Seitz C. Guidelines on Urolithiasis. uroweb.org/wp-content/uploads/EAU-Guidelines Urolithiasis2015v2.pdf. Accessed March 2015.

2. Bucuras V, Gopalakrishnam G, Wolf JS, Sun Y, Bianchi G, Erdogru T, de la Rosette J. The Clinical Research Office of The Endourological Society 
Percutaneous Nephrolithotomy Global Study; nephrolithotomy in 189 patients with solitary kidneys. J Endourol 2012;26:336-341.

3. Akman T, Binbay M, Terkinarslan E, Ozkuvanci U, Kezer C, Erbin A, Berberoglu Y, Yaser-Muslumanoglu A. Outcomes of percutaneous nephrolithhotomy in patients with solitary kidneys: a single-center experience. Urology $2011 ; 78: 272-276$

4. Wong KA, Sahai A, Patel A, Thomas K, Bultitude M, Glass J. Is Percutaneous Nephrolithotomy in Solitary Kidneys Safe? Urology 2013;82:1013-1016.

5. Resorlu B, Kara C, Oguz U, Bayindir M, Unsal A. Percutaneous nephrolithotomy for complex caliceal and staghorn stones in patients with solitary kidney. Urol Res 2011;39:171-176.

6. Mahboub MR, Shakibi MH. Percutaneous nephrolithotomy in patients with solitary kidney. Urol J 2008;5:24-27.

7. Michel MS, Trojan L, Rassweiler JJ. Complications in Percutaneous Nephrolithotomy. Eur Urol 2007;51:899-906.

8. Thomas K, Smith NC, Hegarty N, Glass JM. The Guy's stone score-grading the complexity of percutaneous nephrolithotomy procedures. Urology 2011;78:277-281.

9. Smith A, Averch TD, Shahrour K, Opondo D, Daels FP, Labate G, Turna B, de la Rosette JJ. A nephrolithometric nomogram to predict treatment success of percutaneous nephrolithotomy. J Urol 2013;190:149-156.

10. Okhunov Z, Friedlander JI, George AK, Duty BD, Moreira DM, Srinivasan AK, Hillelsohn J, Smith AD, Okeke Z. S.T.O.N.E. nephrolithometry: novel surgical classification system for kidney calculi. Urology 2013;81:1154-1159.

11. Jeong CW, Jung JW, Cha WH, Lee BK, Lee $S$, Jeong SJ, Hong SK, Byun SS, Lee SE. Seoul National University Renal Stone Complexity Score for Predicting Stone-Free Rate after Percutaneous Nephrolithotomy. PloS One 2013;8:e65888.

12. Vicentini FC, Marchini GS, Mazzucchi E, Claro JF, Srougi M. Utility of the Guy's stone score based on computed tomographic scan findings for predicting percutaneous nephrolithotomy outcomes. Urology 2014;83:1248-1253.

13. Ingimarsson JP, Dagrosa LM, Hyams ES, Pais VM Jr. External validation of a preoperative renal stone grading system: reproducibility and interrater concordance of the Guy's stone score using preoperative computed tomography and rigorous postoperative stone-free criteria. Urology 2014;83:45-49.

14. Sfoungaristos S, Gofrit ON, Yutkin V, Landau EH, Pode D, Duvdevani M. External Validation of CROES Nephrolithometry as a Preoperative Predictive System for Percutaneous Nephrolithotomy Outcomes. J Urol 2016;195:372376.

15. Bozkurt IH, Aydogdu O, Yonguc T, Yarimoglu S, Sen V, Gunlusoy B, Degirmenci T. Comparison of Guy and Clinical Research Office of the Endourological
Society Nephrolithometry Scoring Systems for Predicting Stone-Free Status and Complication Rates After Percutaneous Nephrolithotomy: A Single Center Study with 437 Cases. J Endourol 2015;29:1006-1010.

16. Labadie K, Okhunov Z, Akhavein A, Moreira DM, Moreno-Palacios J, Del Junco M, Okeke Z, Bird V, Smith AD, Landman J. Evaluation and comparison of urolithiasis scoring systems used in percutaneous kidney stone surgery. J Urol 2015;193:154-159.

17. Sfoungaristos $S$, Gofrit ON, Yutkin V, Landau EH, Pode D, Duvdevani M. Evaluating Parameters Affecting Fluoroscopy Time During Percutaneous Nephrolithotomy: Focus on the Predictive Role of Guy's, S.T.O.N.E., and CROES Scoring Systems. J Endourol 2015;29:1366-1370.

18. Withington J, Armitage J, Finch W, Wiseman O, Glass J, Burgess N. Assessment of Stone Complexity for PCNL: A Systematic Review of the Literature, How Best Can We Record Stone Complexity in PCNL? J Endourol 2016;30:13-23.

19. Klaipetch A, Namwongprom S, Ekmahachai M, Lojanapiwat B. Excretory urography and renal scintigraphy for chronic obstructed kidney: does nonopacity mean nonsalvageability? Singapore Med J 2013;54:267-270.

20. Levey AS, Stevens LA, Schmid CH, Zhang YL, Castro AF 3rd, Feldman HI, Kusek JW, Eggers $P_{1}$ Van Lente $F_{1}$ Greene $T$, Coresh J. A new equation to estimate glomerular filtration rate. Ann Intern Med 2009;150:604-612.

21. Tefekli A, Karadag MA, Tepeler K, Sari E, Berberoglu Y, Baykal M, Sarilar 0 , Muslumanoglu AY. Classification of percutaneous nephrolithotomy complications using the modified Clavien grading system, looking for a standard. Eur Urol 2008;53:184-190.

22. Ozden E, Mercimek MN, Yakupoğlu YK, Ozkaya O, Sarikaya S. Modified Clavien classification in percutaneous nephrolithotomy: Assessment of complications in children. J Urol 2011;185:264-268.

23. Hosseini MM, Yousefi $A$, Hassanpour A, Jahanbini $S$, Zaki-Abbasi $M$. Percutaneus Nephrolitotomy in Solitary Kidneys: Experience with 412 Cases from Southern Iran. Urolithiasis 2015;43:233-236.

24. Torricelli FC, Padovani GP, Marchini GS, Vicentini FC, Danilovic A, Reis ST, Srougi M, Mazzucchi E. Percutaneous nephrolithotomy in patients with solitary kidney: a critical outcome analysis. Int Braz J Urol 2015;41:496-502.

25. Oguz U, Resorlu B, Ozyuvali E, Bozkurt OF, Senocak C, Unsal A. Categorizing intraoperative complications of retrograde intrarenal surgery. Urol Int 2014;92:164-168.

26. Alenezi H, Denstedt J. Flexible ureteroscopy: Technological advancements, current indications and outcomes in the treatment of urolithiasis. Asian J Urol 2015;2:133-141.

27. Gao $X$, Peng $Y$, Shi $X$, et al. Safety and efficacy of retrograde intrarenal surgery for renal stones in patients with a solitary kidney: a single-center experience. J Endourol 2014;28:1290-1294. 